\title{
Epidemiological Particularities and Indications of the Mutilating Surgery of the Eyeball in Abidjan (Ivory Coast)
}

\author{
Sowagnon Thierry Yves Constant ${ }^{1}$, Bilé Philippe Emile France Koffi², Irie Bi Gohi Serge ${ }^{3}$, \\ Koman Chatsé Ellalie ${ }^{4}$, Diomandé Gossé Francois², Kra Alla N'goran Siméon", \\ Konan Manmi Sienou Marguerite Pascaline², Détchi Honorat ${ }^{4}$, Koné Safédé1, \\ Kouassi Francois Xavier ${ }^{4}$ \\ ${ }^{1}$ Ophthalmology Department of the University Hospital Center of Yopougon, Yopougon, Ivory Coast \\ ${ }^{2}$ Ophthalmology Department of the University Hospital Center of Bouake, Bouake, Ivory Coast \\ ${ }^{3}$ Anesthesia and Resuscitation Department of the University Hospital Center of Bouake, Bouake, Ivory Coast \\ ${ }^{4}$ Ophthalmology Department of the University Hospital Center of Cocody, Cocody, Ivory Coast \\ Email:iriebi_gohiserge@yahoo.fr
}

How to cite this paper: Constant, S.T.Y., Koffi, B.P.E.F., Serge, I.B.G., Ellalie, K.C., Francois, D.G., Siméon, K.A.N., Pascaline, K.M.S.M., Honorat, D., Safédé, K. and Xavier, K.F. (2018) Epidemiological Particularities and Indications of the Mutilating Surgery of the Eyeball in Abidjan (Ivory Coast). Open Journal of Ophthalmology, 8 , 91-96.

https://doi.org/10.4236/ojoph.2018.82013

Received: April 10, 2018

Accepted: May 8, 2018

Published: May 11, 2018

Copyright (c) 2018 by authors and Scientific Research Publishing Inc. This work is licensed under the Creative Commons Attribution International License (CC BY 4.0).

http://creativecommons.org/licenses/by/4.0/

\section{(c) (i) Open Access}

\begin{abstract}
Objective: To describe the epidemiological profile and indications of mutilating eyeball surgery in Abidjan. Patients and methods: This is a retrospective descriptive study on the files of eviscerated, enucleated or exentered patients in the Ophthalmology Department of the University Hospital of Yopougon from January 2010 to December 2016. The parameters studied were: socio-demographic characteristics, indications of mutilating surgery, anesthetic technique, operative technique and patient evolution. Results: During the study period, 59 patients underwent surgery for mutilating eye surgery out of a total of 11,114 procedures, a frequency of $0.53 \%$. The average age of the patients was 31 years with extremes of 3 years and 67 years. Men predominated in $62.1 \%$ of cases with a sex ratio of 1.64 . Patients came from rural areas in $68.5 \%$ of cases. The main indications of the mutilating surgery were: post-inflammatory phthisis (58.6\%) and tumoral affections (29.31\%). Evisceration was the most common operative technique (67.2\%). In $68 \%$ of cases the interventions were performed under peribulbar anesthesia. Patients with evisceration (67.2\%) and enucleation (5.1\%) all benefited from prosthetic equipment. Conclusion: The mutilating surgery of the eyeball is responsible for serious psychological and sociological impacts. The seriousness of these repercussions requires primary prevention through early and adequate management of eye conditions.
\end{abstract}

\section{Keywords}

Mutilating Surgery, Anesthesia, Evisceration, Enucleation, Exenteration 


\section{Introduction}

The mutilating surgery of the eyeball is the removal of the eyeball with or without its appendages. It is indicated when no conservative therapy is not possible. Its annual incidence is $1.9 \%$ to $4.2 \%$ in Nigeria [1] and $1.40 \%$ in Nepal [2]. The different operating techniques used are evisceration, enucleation and exenteration. Evisceration consists in the removal of ocular contents by respecting the sclera generally followed by the placement of an orbital implant to replace the ocular volume lost [3]. It can be classic with amputation of the cornea or so-called conservative. Enucleation, in turn, consists of the removal of the eyeball and the most anterior part of the optic nerve. Respect of the conjunctiva and oculomotor muscles is fundamental during this surgical technique. Exenteration consists of the bulk excision of the orbital content and its periosteal envelope with or without the eyelids, leaving bare the bony walls of the orbit. These mutilating surgeries are responsible for serious social and sociological repercussions. Indeed, the patient loses all hope of recovering the vision and will appear vis-à-vis society as a handicapped [4]. The aim of this work is to describe the epidemiological characteristics and main indications of mutilating surgery in order to identify primary prevention actions.

\section{Patients and Methods}

This was a descriptive retrospective study conducted in the Ophthalmology Department of the University Hospital Center of Yopougon from January 2010 to December 2016. All patients who had undergone mutilating surgery of the eyeball and having a medical file have been selected for our study. We obtained the favorable agreement of the ethics committee of our hospital before starting this study. The studied parameters were: the socio-demographic characteristics, the indications of the mutilating surgery, the anesthetic technique, the operative technique and the evolution of the patients. These studied parameters were collected from patients' medical records. Chi-square and exact Fischer tests were used for statistical analysis.

\section{Results}

During the study period, 58 mutilating surgeries were performed on a total of 11,114 surgical procedures, for a frequency of $0.52 \%$. There was male predominance in the study population (61.2\%) with a sex ratio of 1.64 . Subjects aged between 1 and 14 years made up 36.2\% of our series (Table 1). The average age of the patients was 31 (range: 3 years and 67 years). Patients were from rural areas in $68.5 \%$ of cases. Mutilative surgery was performed on only one eye in all cases and involved the left eye in $55.1 \%$ of cases (Table 2). All patients had benefited from previous treatment which in 55\% of cases was achieved with the administration of traditional substances in the eye. Indications of mutilating eyeball surgery were dominated by infectious (58.4\%) and tumoral (29.1\%) pathologies (Table 3). Keratopathies (41.37\%) were the main infectious diseases 
Table 1. Distribution of patients by age $(n=58)$.

\begin{tabular}{ccc}
\hline Age Groups & Number & Percentage \\
\hline $1-14$ year & 21 & 36.2 \\
$15-29$ year & 12 & 20.6 \\
$30-44$ years & 06 & 10.3 \\
$45-59$ years & 09 & 15.5 \\
$>50$ years & 10 & 17.2 \\
\hline
\end{tabular}

Table 2. Distribution of patients by eye $(n=58)$.

\begin{tabular}{ccc}
\hline Affected Eye & Number & Percentage \\
\hline Law & 26 & 44.8 \\
Left & 32 & 55.1 \\
\hline
\end{tabular}

Table 3. Distribution of patients by etiologies $(n=58)$.

\begin{tabular}{|c|c|c|c|}
\hline \multicolumn{2}{|r|}{ Etiologies } & \multirow{2}{*}{$\begin{array}{c}\text { Number } \\
03\end{array}$} & \multirow{2}{*}{$\begin{array}{c}\text { Percentage } \\
5.1\end{array}$} \\
\hline Inflammatory & Acne abscess & & \\
\hline and infectious & Corneal ulcer & 07 & 12 \\
\hline diseases & keratopathies & 24 & 41.3 \\
\hline \multicolumn{2}{|c|}{ Traumatic conditions } & 07 & 12 \\
\hline \multirow{4}{*}{$\begin{array}{c}\text { Tumor } \\
\text { pathologies }\end{array}$} & Retinoblastoma & 07 & 12 \\
\hline & Rhabdomyosarcoma & 03 & 5.1 \\
\hline & $\begin{array}{l}\text { Squamous cell carcinoma of } \\
\text { the conjunctiva }\end{array}$ & 05 & 8.6 \\
\hline & Choroidal melanoma & 02 & 3.4 \\
\hline
\end{tabular}

and retinoblastoma the most observed tumor disease (12.07\%) (Table 3). Peribulbar anesthesia was the main anesthetic technique (68\%). General anesthesia was mostly performed in children. The surgical techniques used were: evisceration (67.2\%), exenteration (27.5\%) and enucleation (5.1\%) (Table 4). Patients with evisceration (67.2\%) and enucleation (5.1\%) all benefited from prosthetic equipment (placement of silicone ball internally and ocular prosthesis externally). The duration of hospitalization was $72 \mathrm{~h}$ for exentations and $48 \mathrm{~h}$ for eviscerations and exerrations. Complications observed were: silicone ball extrusion $(10.3 \%)$ and tumor recurrence with metastases (17.2\%). Lethality was $3.4 \%$ in our series.

\section{Discussion}

The frequency of the mutilating surgery in our study was $0.53 \%$. This frequency is lower than those reported by Pandley in Nepal [2], Eballé in Cameroon [5] and Vonor in Togo [6], which were 1.4\% [2], 1.6\% [5] and 1\%, respectively [6]. Our study population in $61.2 \%$ of cases was male. This male predominance 
Table 4. Distribution of patients by surgical technique $(n=58)$.

\begin{tabular}{ccc}
\hline Surgical technique & Number & Percentage \\
\hline Evisceration & 39 & 67.2 \\
Exenteration & 16 & 27.5 \\
Enucleation & 03 & 5.1 \\
\hline
\end{tabular}

can be explained on the one hand by the greater acceptance of men for this type of surgery and, on the other hand, by their high exposure to trauma. Subjects from rural areas made up $68.5 \%$ of our series. These were subjects practicing in the agricultural field with an activity that represented a significant factor of exposure of the eyes. These subjects frequently used traditional herbal treatments to treat conditions of interest to their eyes. This situation explains the significant rate of self-medication observed in our study $(55.20 \%)$ as reported by many authors [7] [8]. Self-medication with various medications and the absence of treatment are other major reasons that lead these patients to consult at the stage where functional recovery surgery is no longer possible. Indeed, contrary to the goal of cataract surgery, which aims to improve vision; the main goal of mutilating surgery is to improve the patient's quality of life [7]. The etiologies of this surgery in our study were dominated by infectious pathologies $(58.61 \%)$ and tumoral affections (29.30\%) Our findings were superimposable with those of Kagmeni [8], Pandey [2], Nwosu [1]. These results differed from those of Diomandé [9] and Meda [10], who observed a predominance of traumatic pathologies in their series. The high frequency of infectious diseases in the present study can be explained by their inadequate management of their active phase by corticosteroid eye drops in self-medication and by traditional preparations based on plants. Retinoblastoma was the main tumor condition responsible for mutilating surgery in our study. Delayed consultation explained the predominance of extra-ocular forms. These forms exclude any conservative treatment and often result in death despite clean surgery, especially in the absence of chemotherapy or radiotherapy. The challenge in our environments for retinoblastoma is the early diagnosis for conservative treatment. Peribulbar anesthesia was the most commonly performed anesthetic technique for mutilating surgery in our series (68\%). According to Calenda [11], it is a safe technique with the advantage of optimal analgesia in per and postoperative evisceration or enucleation. In our study, evisceration was the most common type of mutilating surgery (67.2\%), followed by exenteration (27.5\%) and enucleation (5.1\%) according to data from the literature [2] [5]. Evisceration indications are ocular complications of trauma or infection [12]. Enucleations mainly concern tumor pathologies and trauma [2] [13]. The adaptation of an ocular prosthesis was performed in $72.3 \%$ of our patients. The placement of the prosthesis is essential to reduce the aesthetic damage, but the maintenance of the prosthesis requires education and cooperation of the patient to avoid infectious complications. In children, to avoid these prejudices and to allow a good continuity of the orbital development, it is advis- 
able the transplant graft [14]. Mutilating surgery is a radical decision that must be made after eliminating all alternatives such as lamellar keratotomy, conjunctival overlay, or corneal tattooing. The corneal tattoo using the dermatologist is an alternative with satisfactory aesthetic results in case of corneal leukemia [15].

\section{Limitations of the Study}

This study has many biases because of its retrospective nature and the fact that all patients to benefit from a mutilating surgery of the eyeball were only supported by the University Hospital of Yopougon. However, it allows describing for the first time, the main etiologies and the surgical management of the mutilating surgery of the eyeball in Abidjan.

\section{Conclusion}

Mutilating surgery is a heavy, traumatic and dramatic intervention that has a devastating effect on the patient's psychology. Reducing the incidence of this surgery requires early diagnosis and appropriate treatment of infectious diseases, trauma and tumors.

\section{References}

[1] Nwosu, S.N. (2005) Destructive Ophthalmic Surgical Procedures in Onitsha, Nigeria. Nigerian Postgraduate Medical Journal, 12, 53-56.

[2] Pandey, P.R. (2006) A Profile of Destructive Surgery in Nepal Eye Hospital. Kathmandu University Medical Journal, 4, 65-69.

[3] Phan, L.T., Hwang, T.N. and McCulley, T.J. (2012) Evisceration in the Modern Age. Middle East African Journal of Ophthalmology, 19, 24-33. https://doi.org/10.4103/0974-9233.92113

[4] Limbu, B., Saiju, R. and Ruit, S. (2009) A Retrospective Study on the Causes for Evisceration at Tilganga Eye Center. Kathmandu University Medical Journal, 7, 115-119.

[5] Eballé, A.O., Dohvoma, V.A., Kokoi, G., Oumarou, A., Bella, A.L., et al. (2011) Indications for Destructive Eye Surgery at Yaoundé Gynaeco-Obstetric and Paediatric Hospital. Clinical Ophthalmology, 5, 561-565.

https://doi.org/10.2147/OPTH.S18449

[6] Vonor, K., Amedome, K.M., Dzidzinyo, K., Ayena, K.D., Santos, M.K.A., et al. (2015) Bilan de dix ans de chirurgies mutilantes oculaires à Lomé. Médecine et Santé Tropicales, 25, 177-179.

[7] Kennedy, R.E. (1979) Indications and Surgical Techniques for Orbital Exenteration. Ophthalmology, 86, 967-973. https://doi.org/10.1016/S0161-6420(79)35462-8

[8] Kagmeni, G., Noche, C.D., Nguefack-Tsague, G. and Wiedemann, P. (2004) Indications for Surgical Removal of the Eye in Rural Areas in Cameroun. Ophthalmology and Eye Diseases, 6, 27-30.

[9] Diomandé, I.A., Diomandé, G.F., Bilé, P.E.F.K., Sévédé, D., Ouattara, Y., et al. (2013) La chirurgie mutilante et ses indications en ophtalmologie. Revue Internationale du Collège d'odonto-Stomatologie et de Chirugie Maxillo-Faciale Africain, 20, 53-58. 
[10] Méda, N., Ouédraogo, A., Daboué, A., et al. (2001). Etiologies des traumatismes oculo-palpébraux au Burkina Faso. Journal Francais D’Ophtalmologie, 5, 463-466.

[11] Calenda, E., Retout, A. and Muraine, M. (1999) L'anesthésie péribulbaire pour le contrôle de la douleur per et postopératoire au cours des énucléations ou éviscérations : Trente et un cas. Journal Francais D’Ophtalmologie, 22, 426-430.

[12] Adenis, J.P., Rulfi, J.Y. and Rober, P.Y. (2001) Eviscération selon la technique de la poupée russe ou du parachute. Journal Francais D'Ophtalmologie, 24, 887-892.

[13] Tahri, H., Benatya, A.D., Chefchaouni, C.M., El Bakkali, M. and Berraho, A. (2004) Enucléations: enquête épidémiologique marocaine à propos de 183 cas. Bulletin de La Société Belge d'Ophtalmologie, 292, 31-34.

[14] Gotzamanis, A., Ducasse. A., Brugniart, C. and Sayag, D. (2001) La greffe dermograisseuse. Utilisation en chirurgie de reconstruction. Journal Francais D’Ophtalmologie, 24, 617-622.

[15] Rocher, N., Hirst, L., Renard, G., Doat, M., Bourges, J.L., et al. (2008) De l'usage du tatouage cornéen. A propos de 14 cas. Journal Francais D'Ophtalmologie, 31, 968-974. https://doi.org/10.1016/S0181-5512(08)74742-9 